\title{
A DIAGNOSTIC FOR EARNINGS MANAGEMENT USING CHANGES IN ASSET TURNOVER AND PROFIT MARGIN: EVIDENCE FROM PALESTINE EXCHANGE
}

\author{
DOI: 10.17261/Pressacademia.2021.1388 \\ JEFA- V.8-ISS.1-2021(7)-p.67-82
}

Israa Al-Madhoun ${ }^{1}$, Hisham Kamel Madi², Mohammed Marwan Alashi ${ }^{3}$

${ }^{1}$ Islamic University of Gaza, Department of Accounting, 108, Gaza, Palestine. esraaesraahamed@hotmail.com, ORCID: 0000-0003-2973-7703

${ }^{2}$ Islamic University of Gaza, Department of Accounting, 108, Gaza, Palestine. hmadi@iugaza.edu.ps, ORCID: 0000-0001-9477-8013

3 Islamic University of Gaza, Department of Accounting, 108, Gaza, Palestine. malashi@iugaza.edu.ps, ORCID: 0000-0002-9492-3716

\begin{tabular}{l} 
Date Received: January 9, $2021 \quad$ Date Accepted: March 27, $2021 \quad$ open Oaccess $\quad$ (cc) BY \\
\hline To cite this document \\
Al-Madhoun, I., Madi, H. K., Alashi, M. A.,(2021). A diagnostic for earnings management using changes in asset turrnover and profit \\
margin: evidence from Palestine Exchange. Journal of Economics, Finance and Accounting (JEFA), V.8(1), p.67-82. \\
Permanent link to this document: $h$ http://doi.org/10.17261/Pressacademia.2021.1388 \\
Copyright: Published by PressAcademia and limited licensed re-use rights only.
\end{tabular}

\section{ABSTRACT}

Purpose - This paper aims to evaluate whether the earnings management diagnostic using changes in asset turnover and profit margin as proposed by Jansen et al., (2012) is informative in identifying earnings management

Methodology - Two tests were employed: firstly, the association between the diagnostic and discretionary accruals using Kothari et al., (2005) model, was tested by using Pearson correlation and contingency tables. Secondly, by using future profitability reversals as an indicator of earnings management, the investigation of whether the diagnostic has incremental information in identifying earnings management as compared to Kothari et al., (2005) model was performed using multivariate regression analysis. Data wa s collected for the period from 2006 to 2017 and comprises a total of $(3,108)$ firm-year observations from the Palestinian stock exchange.

Findings- The results indicate that the diagnostic proposed by Jansen et al., (2012) is a useful indicator for earnings management, as well as this diagnostic, provides higher information content in identifying earnings management than the discretionary accruals model i.e. Kothari et al., (2005) model.

Conclusion- This study contributes to the limited earnings management literature in emerging economies generally, and in the Palestinian context particularly. The results of the study benefit financial statement users to have diagnostics for earnings management that are informative.

Keywords: Earnings management, discretionary accruals, future profitability reversals, Palestine Exchange. JEL Codes: M40, M41

\section{INTRODUCTION}

The existence of information asymmetries between the firm's managers and its stakeholders, including stockholders, creditors, and suppliers, creates the need for a summary measure of firm performance (Dechow, 1994). This introduces the choice between realized cash flows or earnings as a summary measure, more precisely, that means the trade-off between adopting cash or accrual basis of accounting (Cohen and Zarowin, 2008; Chamberlain et al., 2014). While realized cash flows have timing and matching problems that cause them to be a noisy measure of firm performance. The use of accruals, on the other hand, introducing a new problem because managers can use discretion over the recognition of accruals (Dechow, 1994; Badertscher, 2011; Chamberlain et al., 2014). Although Holthausen and Leftwich, (1983); Watts and Zimmerman (1978), and others argued that using discretion can enhance the ability of earnings as a measure of a firm's performance because managers have more information about the firm's operations, this discretion can be exploited opportunistically to manipulate accruals. In general, earnings management "EM hereafter" can be viewed as the utilization of this discretion in financial reporting (Höglund, 2010; Cohen and Zarowin, 2010).

Analyzing and measuring of accrual-based earnings management often focuses on management's use of discretionary accruals. Such research requires a model that estimates the discretionary component of reported income (Dechow et al., 1995). Existing models are usually classified into two categories: first, aggregate accrual models which range from simple models in which discretionary accruals are measured as total accruals such as Healy (1985) and DeAngelo 
(1986) models, to more sophisticated models that attempt to separate total accruals into discretionary and nondiscretionary components, such as Jones model, modified Jones model is also known as Dechow et al., (1995) model. A second category in the literature is to model a specific accrual (McNichols, 2001; McNichols and Wilson, 1988; Petroni, 1992; Nelson et al., 2000).

Although aggregate accruals models made an important contribution to the literature at the time they were introduced and have had a substantial impact, it's suggested that further progress in the literature will require a departure from extensive reliance on aggregate accruals approaches (McNichols, 2001). Acco rding to Dechow et al., (2012), these models lack power for earnings management of plausible magnitudes because of the poor ability of the models to isolate discretionary accruals. Moreover, tests using these models are misspecified due to correlated omitted variables in samples with extreme financial performance. An alternative tool has therefore been sugge sted by Jansen et al., (2012) based on the assumptions underlying the DuPont analysis that sales are a driver of both the company's income and its investment i.e. operating assets. Therefore, in cases of absent EM, the change in the asset turnover ratio (ATO, hereafter) (Sales/Net operating Assets) and the change in the profit margin ratio (PM, hereafter) (Operating Income/Sales) go in the same direction. Therefore, Jansen et al., (2012) has exploited this accounting intuition to propose a simplistic diagnostic for earnings management that if the change in the ATO and the change in the PM go in an opposite direction simultaneously, then this could be consi dered as a sign for upward or downward EM. In this vein, and according to Rani et al., (2013), emerging economies such as the Palestinian economy have not taken considerable attention in the prior earnings management literature, although, the EM practices introduced in these economies. For example, Hessayri and Saihi (2015) provide evidence on the EM practices in different emerging economies including, the United Arab Emirates, Morocco, South Africa, and the Philippines, and these practices have not been reduced after the adoption of IFRS. Additionally, Alareeni and Aljuaidi (2014) argued that both Yoon et al., (2006) and modified Jones models are weak in detecting EM in the Palestinian context, the study suggests that the development of a new model is crucial for emerging economies such as Palestinian one.

Based on the above discussion, the purpose of this paper is to consider whether the Jansen et al., (2012) diagnostic is informative for detecting EM in the Palestinian context. This paper is considered use ful and contributes to the existing literature on earnings management in several ways. First, the existing researches in earnings management area conducted in emerging economies are very limited as compared to those conducted in the developed econ om ie s to test the suitability of models developed to detect earnings management in such economies. Second, it is notewort hy that most of the studies conducted in such economies suffer from a short study period (Hessayri and Saihi, 2015; Abdelkarim and Zuriqi, 2020; Alareeni and Aljuaidi, 2014; Alzoubi, 2018; Bao and Lewellyn, 2017; Lassoued et al., 2020), this study complements the existing literature by collecting and analyzing more recent data over a much longer period, more specifically, over (12) years from 2006-2017 which strengths the estimation of variables and parameters statistically. Third, almost most studies in the EM area have been conducted to investigate the power and specification of accrual-based models. To the best of research knowledge, there are very limited published studies, which investigate the effectiveness of this diagnostic. Therefore, this study will contribute in generalizing this method, particularly, in emerging economies. Finally, all studies that have employed aggregate accruals EM models, have linked the existence of EM with a specific incentive e.g. equity offering, managers' compensation or bonus plans, debt covenants, tax incentives (Abdelkarim and Zuriqi, 2020; Bao and Lewellyn, 2017). However, in generic settings whe re an obvious incentive to manage earnings is absent, the situation would be more complex to identify EM using such models. Thus, financial statement users need to have diagnostics for EM that are informative even when no obvious incentive to manage earnings exist. Therefore, this diagnostic is considered to be useful in the Palestinian context as managerial incentives to manage earnings aren't obvious (Alareeni and Aljuaidi,2014; Abdelkarim and Zuriqi, (2020) and there's a lack of studies which covered such topics. This research is organised as follows: section 2 present a summary of developed methods pertaining earnings mamagement and hypothesis development is preseneted as well. Research methodology is presented in section 3. Findings and data analysis are presented in section 4. Conclusion and summary are presented in secion 5 .

\section{LITERATURE REVIEW AND HYPOTHESIS DEVELOPMENT}

\subsection{Review of the Developed Models}

Dechow et al., (1995) (DSS, hereafter) provided systematic evidence on the relative performance of aggregate accruals models, by comparing the specification and power of commonly used test statistics. The models reviewed include Healy (1985) who used total accruals and DeAngelo (1986) who used the change in total accruals as a proxy for earnings management. Both models implicitly assuming that nondiscretionary accruals are constant proxies. Because nondiscretionary accruals are expected to change with firms' underlying business activities, this assu $\mathrm{mption}$ is unlikely to be empirically descriptive. Therefore, the Jones model (1991) has been developed to relax this assumption and predict nondiscretionary accruals by including the change in total revenues (cash and credit) and the level of the gross property, plant, and equipment as determinants of non-discretionary accruals. 
DSS also evaluated the power of these models by examining the frequency with which these test statistics generate a type II error. Type II error arises when some discretionary accruals that are unintentionally removed from discretionary accruals proxy, i.e. models fail to isolate the discretionary accruals, resulting in decreasing the probability of rejecting the null hypothesis of no EM when it's false, and that in turn leads to a lower power of the se tests. DSS also evaluated the specification of these models by examining the frequency with which these test statistics generate type I error. Type I error arises when some nondiscretionary accruals are unintentionally left in the discretionary accruals proxy, due to correlated omitted variables in samples with extreme financial performance. That's because these tests identified factors that don't cause earnings to be managed, but are correlated with firm performance as a stimulus for earnings management, which in turn results in misspecification of these models, and increasing the probability of rejecting the null hypothesis of no earnings management when it's true. DSS proposed a modified version of the Jones model (1991), in an attempt to mitigate the frequency of type II error, thus incre asing the power of the model, DSS concluded that the original Jones model has low power in cases where firms manipulate revenue through the misstatement of net accounts receivable. This is because the original Jones model incl ude s the change in credit sales as a determinant of non-discretionary accruals, resulting in the removal of discretionary accruals (type II error). To mitigate this problem, DSS suggested that cash revenue be used in place of reported revenue in the event period. Finally, DSS concluded that although all these models appear to be well specified whe $n$ they are applied to a random sample of firm-years, they have low power for EM of economically plausible magnitudes (less than $5 \%$ of total assets), and they are misspecified when they are applied to a firm with extreme financial performance because of the existence of omitted correlated variables. The study also emphasized that the modified Jones model provides more powerful tests of EM. In contrast, Beneish (2001) examines the ability of DSS' modified Jones model to identify EM by firms identified as generally accepted accounting principles (GAAP) violators, eithe $r$ by the financial press or the SEC Enforcement Division. He finds that the modified Jones model does not perform well in detecting GAAP violators.

In a subsequent study, McNichols (2001) was the first one who overviewed the trade-offs associated with the most common three research designs used in the EM literature: those based on aggregate accruals, specific accruals, and those based on the distribution of earnings after management. The study

provided evidence on the misspecification of these models due to the ignorance of long-term earnings growth, i.e. correlated omitted variables. Concerns that mentioned models fail to capture all non-discretionary accruals, because of the existence of omitted correlated factors, such as financial performance, have led researchers to enhance the se models with performance matching procedures.

Kothari et al., (2005) were the first who proposed a performance-based accrual model. They supplement Jones and Modified Jones models by controlling for performance using the return on assets (ROA) as a matching variable. The study made two tests to control for the effect of performance on estimated discretionary accruals: the first is a regression-based approach by extending Jones and modified Jones models by including ROA as an additional independent variable (this approach used previously in the literature such as Dechow and Dichev (2002) who have used operating cash flows). The second is a performance-matched approach where abnormal discretionary accruals are defined relative to the discretionary accruals for a firm with similar performance i.e. the same ROA.

The comparative results showed that tests of discretionary accruals using a performance-matched approach are better specified than those using a linear regression-based approach. This result is due to the non-linear relationship between accruals and performance which has been identified by many preceding researchers (Beaver and Demski, 1979; Brooks and Buckmaster, 1976; Freeman and Tse, 1992). In this vein, Dechow et al. (2012) (DHKS, hereafter), showed that these performance-based accrual models cause substantial reductions in test power and are only effective when the matching procedure employs the relevant omitted variable, i.e. mitigate misspecification when the matching procedure employs the relevant omitted variable. Jansen et al., (2012) also proposed a simple diagnostic of earnings management that is simple and far away from accrual-based models. This diagnostic relies on the widely held notion underlying DuPont analysis (where a firm's return on assets is decomposed into asset tu rnover (ATO, the ratio of sales to net operating assets) and profit margin (PM, the ratio of operating income to sales), that sales is a fundamental driver of both the company's income and its investment i.e. operating assets, and because of the nature of double-entry accounting which is reflected in the articulation of the income statement and balance sheet, net operating assets on the balance sheet and net operating income on the income statement should vary directly with sales, thus change in both ATO and PM should be in the same direction. In other words, if changes in ATO and PM are in an opposite direction then this could be a signal of EM. Specifically, the simultaneous increase in ATO and decrease in PM may indicate a downward earnings management, and the simultaneous decrease in ATO and increase in PM may indicate an upward earnings management.

Because earnings management can't be directly observable, the study identified firms that are suspected to be engaged in EM-based on four indicators or outcomes of earnings management, and test whether PM/ATO diagn ostic is associated with these earnings management indicators: firms which meet or beat analysts' expectations, firms which report extreme earnings surprises, those which subsequently restate earnings upwards, and those which 
experience a reversal in year-ahead profitability or produce predictable year-ahead abnormal returns. In all these four perspectives the study compares the relative and incremental information content of the PM/ATO diagnostic to the performance-adjusted accruals model proposed by Kothari et al., (2005). The results show that in each of these analyses the PM/ATO diagnostic provides incremental information over the performance-adjusted accruals model i.e. Kothari et al., (2005) model.

Consistent with Jansen et al., (2012) results, Hejazi et al., (2014) have evaluated the effectiveness of this diagnostic as compared to the modified Jones model using a sample of 100 companies listed in the Tehran Stock exchange. The paper found that the diagnostic provides higher information content than discretionary accrual mod els in detecting EM. These results are also supported by Harebottle (2016) who investigated the diagnostic using a sample of 212 listed South African firms and demonstrated that this diagnostic is a useful indicator for identifying EM. Therefore, this paper attempts to test the effectiveness of this diagnostic in the Palestinian context.

\subsection{Hypotheses Development}

As mentioned above Jansen et al., (2012) argue that changes in ATO and PM in opposite directions could signal EM. More clearly, upward EM will increase operating income, which in turn will lead to an increase in PM. On the other hand, upward EM will overstate net operating assets which in turn will lead to a decrease in ATO. For example, if the firm decides to manipulate earnings upward by reducing the assessment of bad debt expenses, this will overstate operating income and increase in PM. Simultaneously, net operating assets will be also overstated (because net accounts receivables will be higher) which in turn will decrease ATO. Therefore, the first hypothesis will be developed as follows:

\section{H1. The simultaneous increase of PM and the decrease of ATO is a sign of upward earnings management.}

In contrast, downward EM will result in an understatement of operating income, which in turn will lead to a d ecrease in PM. On the other hand, downward EM will result in an understatement of net operating assets which in turn will lead to increase ATO. Accordingly, the second hypothesis will be constructed as follows:

\section{H2. The simultaneous decrease of PM and increase of ATO is a sign of downward earnings management.}

As mentioned above, testing the association between PM/ATO diagnostic and discretionary accruals (measured by Kothari et al., (2005) model) isn't a sufficient investigation of the diagnostic effectiveness, as traditional total accrual models including Kothari et al., (2005) model suffer from specification and power problems as presented in the first chapter and can't be considered as an ideal proxy for EM. On the other hand, Jansen et al., (2012) argue that PM/ATO diagnostic provides incremental information over discretionary accruals in identifying EM. This argument was supported by other researchers who found that the diagnostic is more informative in identifying EM than discretionary accrual models (Hejazi et al., 2014).

Accordingly, the third hypothesis will be constructed as follows:

H3. The PM/ATO diagnostic provides incremental information content over discretionary accruals in identifying earnings management.

Future profitability reversals have been used by preceding researchers as a benchmark of earnings management. Therefore, it can be argued that firms with a contemporaneous increase in PM and a decrease in ATO (upward EM diagnostic) will report lower future profitability than other firms. Therefore, it's expected that the sign for EM-UP's coefficient correlation with future profitability will be negative. On the other hand, firms with a contemporaneous decrease in PM and an increase in ATO (downward EM diagnostic) will report higher future profitability in the subsequent period than other firms (Jansen et al., 2012). Therefore, it's expected that the sign for EM-DN's coefficient correlation with future profitability will be positive.

\section{RESEARCH METHODOLOGY}

\subsection{Data Collection and Sample}

In this study, the data was collected from the annual reports of the sample study for the period of 2007 to 2017 of al I companies listed on the Palestine Exchange. The sample size of the study consists of all Palestinian listed companies as the entire population of the Palestine Exchange. However, the study sample is subjected to the following criteria:

1. The study covers the period from 2006 to 2017, the rationale for using this as the study period is to colle ct the longest possible set of data, thus obtaining a more accurate estimation of models' parameters.

2. Because of the difficulty of separating the financial and operating assets for firms that are engaged in financial services, as required when applying PM/ATO diagnostic, these firms were excluded from the sample. Therefore, all firms in the banking and financial services sector and insurance sector are exclude $d$. Besides, firms in the investment sector that are engaged in financial investment are also excluded. 
Therefore, the final sample includes (28) firm. Therefore, the financial statements variables used in this study should be available for $(3,360)$ firm-year observations, after excluding the missing observations for some firms in which variables are not available, the final sample consists of $(3,108)$ firm -year observations.

\subsection{Research Design}

This study aims primarily to assess the effectiveness of the diagnostic for detecting earnings management proposed by Jansen et al., (2012), more specifically, its suitability in the Palestinian context. The major problem when evaluating the performance of earnings management models is that the actual magnitude of earnings management isn't known, so it's not possible to perform a direct test to validate the diagnostic. Therefore, the diagnostic has been assessed using two different methods used in preceding researches as follows:

First: Using one of the most commonly used EM models which is Kothari et al., (2005) model "a modified version of Jones model (1990)" to obtain discretionary accruals which is a widely used proxy of EM, and measuring how the diagnostic results are correlated to the Kothari et al., (2005) results.

Second: Evaluating the performance of the diagnostic as compared to Kothari et al ., (2005) model by using one-ye ar ahead profitability reversals as earnings management benchmark: according to Penman (2007) EM postpones the reporting of true earnings, thus this will result in a reversal of profitability in the future i.e. if the firm's manage me $n t$ exercises an upward EM in the current period this will result in lower profi tability in the subsequent period than other firms, and if the firm's management exercises a downward EM in the current period, this will result in higher profitability in the subsequent period than other firms. Consistent with this, Dechow et al., (2003); Jansen et al., (2012) have used future profitability reversals as an indicator of EM. Based on those researchers, this intuition is used to investigate the PM/ATO diagnostic ability in identifying EM as compared to discretionary accruals measured by Kothari et al., (2005) model by utilizing multivariate analyses used by Jansen et al., (2012) to predict future profitability reversals.

\subsection{Variable Definitions}

\section{First: PM/ATO Diagnostic}

Jansen et al., (2012) argued that the simultaneous opposite changes in both ATO and PM cloud be an indicator of EM. Accordingly, Jansen et al. (2012) define the signal of upward EM (EM-UP) and the signal of downward EM (EM-DN) as follows:

$\mathrm{EM}-\mathrm{UP}=1$ if $\Delta \mathrm{PM}_{\mathrm{t}}>0$ and $\Delta \mathrm{ATO}_{\mathrm{t}}<0$, and zero otherwise.
$\mathrm{EM}-\mathrm{DN}=1$ if $\Delta \mathrm{PM}_{\mathrm{t}}<0$ and $\Delta \mathrm{ATO}_{\mathrm{t}}>0$, and zero otherwise.

\section{Second: Kothari et al., (2005) Model}

Kothari et al., (2005) model has been used to estimate discretionary accruals. This model is a Jones model augmented with ROA as an independent variable to control for the effect of a firm's performance. it was used widely by much preceding research as a measure of discretionary accruals (Alghamdi and Ali, 2012; Jaggi and Sun, 2006; Jansen et al., 2012; Niu, 2006). Besides, Bhuiyan et al., (2013); Roodposhti et al .,(2012) find that this model provides the most powerful test for earnings management

Table 1: Variable Definitions of PM/ATO Diagnostic

\begin{tabular}{|c|c|}
\hline$\triangle P M_{t}$ & (Operating Incomet / Sales t )- (Operating Income t-1 /Sales t-1) \\
\hline$\triangle A T O_{t}$ & (salest $/$ Net Operating Assetst $)-\left(\right.$ salest-1 $_{\text {N Net Operating Assetst-1) }}$ \\
\hline Operting Income ${ }_{t}$ & $\begin{array}{l}\text { Sales } s_{t}-(\text { cost of goods sold+selling, general and administration+depereication and } \\
\text { amorizatiation expenese })_{t}\end{array}$ \\
\hline Net Operating Asset $s_{t}$ & Net Assets ${ }_{t}-$ Net Financial Assets $t$ \\
\hline Net Financial Assets $s_{t}$ & Cash and short term investments $s_{t}-$ interest bearing liabilities $s_{t}$ \\
\hline Or Net Operating Assets $s_{t}$ & Operating assets - operating liabilities \\
\hline
\end{tabular}

as compared to other discretionary accrual models including Jones (1990), Modified Jones (1995), and Kasznik (1999).

The model presented in the following regression: $T A A C_{\mathrm{t}}$

$$
\frac{T A A C_{t}}{T A_{t-1}}=\propto_{0}\left(\frac{1}{T A_{t-1}}\right)+\propto 1\left(\frac{\triangle R E V_{t}}{T A_{t-1}}\right)+\propto_{2}\left(\frac{P P E_{t}}{T A_{t-1}}\right)+\alpha_{3}\left(R O A_{t}\right)+\varepsilon_{t}
$$




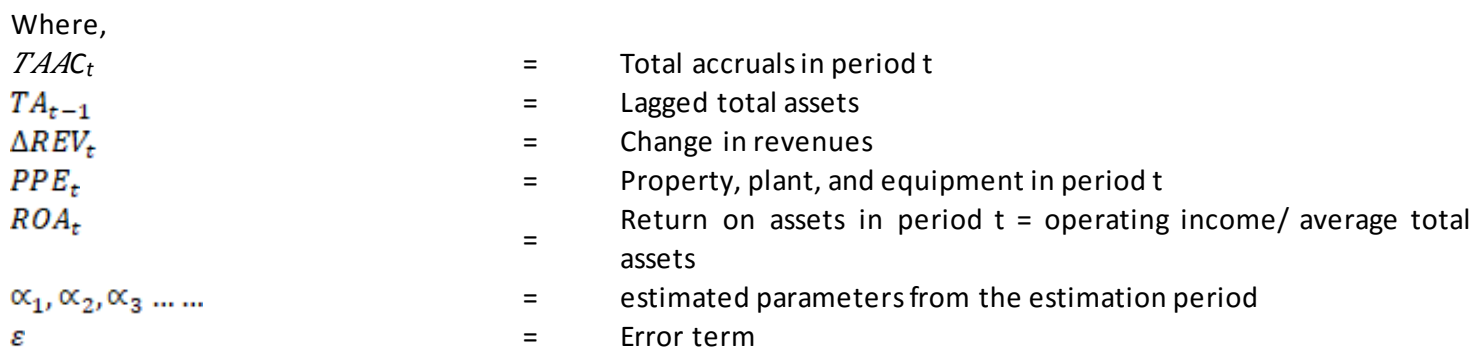

The model was conducted in the following steps:

1.Calculating actual total accruals using the cash flow statement approach. Therefore, the formula is as follow:

2.TAAC $C_{t}=$ Earnings before extraordinary items - Cash flow from operating activities

The model parameters were estimated cross-sectionally. Therefore, the parameters are industry and year specific, which means each industry in each year has specific parameters which are used to estimate nondiscretionary accruals for each firm in this industry each year. To do that, parameters are classified for each sector of listed firms in each year. Parameters are estimated using Kothari et al., (2005) model using the following formula:

$\frac{T A A C_{\mathrm{L}, i}}{T A_{\mathrm{L}-1, i}}=\propto_{0}\left(\frac{1}{T A_{\mathrm{L}-1, i}}\right)+\propto_{1}\left(\frac{\Delta R E V_{\mathrm{E}, i}}{T A_{\mathrm{E}-1, i}}\right)+\propto_{2}\left(\frac{P P E_{\mathrm{L}, i}}{T A_{\mathrm{L}-1, i}}\right)+\alpha_{3}(R O A t, i)+\varepsilon_{t}$

1. Using the estimated parameters to estimate nondiscretionary (normal) accruals by the following formula:

$N D A A C_{t}=\alpha_{0}^{A}\left(\frac{1}{T A_{L-1}}\right)+\propto_{1}^{A}\left(\frac{\Delta R E V_{L}-\triangle R E C_{\mathrm{L}}}{T A_{\mathrm{L}-1}}\right)+\propto_{2}^{\mathrm{A}}\left(\frac{P P E_{\mathrm{L}}}{T A_{\mathrm{L}-1}}\right)+\propto_{3}^{\mathrm{A}}(R O A)$

Where,

$N D A A C_{t}=$ Nondiscretionary (normal) accruals,

$\triangle R E C_{t}=$ change in net receivables

2. Calculating discretionary (abnormal) accruals by subtracting nondiscretionary accruals obtained in step three from total accruals obtained from the first step:

Discetionary accrauls $=$ total accruals - nondiscretionary accruals

\subsection{Research Models}

As mentioned in the research design, it can be argued that firms with a contemporaneous increase in PM and a decrease in ATO (upward EM diagnostic) will report lower future profitability than other firms. Therefore, it is expected that the sign for EM-UP's coefficient correlation with future profitability will be negative. On the other hand, firms with a contemporaneous decrease in PM and an increase in ATO (downward EM diagnostic) will report higher future profitability in the subsequent period than other firms (Jansen et al., 2012). Therefore, it is expected that the sign for EM-DN's coefficient correlation with future profitability will be positive.

Return on net operating assets (RNOA hereafter) is used as a proxy of profitability, and a regression analysis developed by Jansen et al., (2012) to predict one-year RNOA (RNOAt+1) is used. Therefore, this study replicates the model developed by Jansen et al., (2012) to investigate the ability of PM/ATO diagnostic in identifying earnings management as compared to discretionary accruals. Jansen et al., (2012) study according to the literature review has first developed a basic regression analysis for one-year ahead profitability and number of independent variables to control for the dependent variable characteristics (i.e. RNOAt+1), and then add explanatory variables (EM_UP, EM_DN, and Discretionary accruals) gradually to the model to trace the improvement in the explanatory power of each model as explanatory variables are added (Jansen et al., 2012). The study research models as follows:

1. The basic regression analysis is as follows:

$\triangle R N O A_{t+1}=\beta_{0}+\beta_{1} R N O A_{t}+\beta_{2} N O A_{t}+\beta_{3} \triangle R N O A_{t}+\beta_{4} \triangle N O A_{t}+\varepsilon_{t}$

2. The second model includes EM-UP and EM-DN as explanatory variables to test the relation between these variables and future profitability and to test whether adding these variables increases the explanatory power of the model. As EM results in a reversal of profitability in the next period, it's predicted that a significant negative coefficient for the EM-UP variable and a significant positive coefficient for the EM-DN variable (Jansen et al., 2012). The second model is as follows:

$\triangle R N O A_{t+1}=\beta_{0}+\beta_{1} R N O A_{t}+\beta_{2} N O A_{t}+\beta_{3} \Delta R N O A_{t}+\beta_{4} \Delta N O A_{t}+\beta_{5} E M_{U P_{\varepsilon}}+\beta_{6} E M_{D N_{t}}+\varepsilon_{t}$ 
3. The third model includes discretionary accruals measured by Kothari et al., (2005) model as an explanatory variable to compare the correlation significance of this variable toRNOA $A_{t+1}$ as compared to PM/ATO diagnostic variables, so investigating whether the diagnostic provides incremental information in identifying $\mathrm{EM}$ as compared to the discretionary accruals (Jansen et al., 2012). The third model is as follows:

$$
\triangle R N O A_{t+1}=\beta_{0}+\beta_{1} R N O A_{t}+\beta_{2} N O A_{t}+\beta_{3} \Delta R N O A_{t}+\beta_{4} \Delta N O A_{t}+\beta_{5} D A A C_{t}+\varepsilon_{t}
$$

4. The fourth model includes both measures of EM, PM/ATO diagnostic (EM_UP, EM-DN), and discretionary accruals (DAAC), the model is as follows:

$$
\triangle R N O A_{t+1}=\beta_{0}+\beta_{1} R N O A_{t}+\beta_{2} N O A_{t}+\beta_{3} \Delta R N O A_{t}+\beta_{4} \Delta N O A_{t}+\beta_{5} D A A C_{t}+\beta_{6} E M_{U P_{t}}+\beta_{7} E M_{D N_{\varepsilon}}+\varepsilon_{t}(4)
$$

Where $R N O A_{t}$ is Return on net operating assets in period $\mathrm{t}=$ operating income/ average net operating assets, $\Delta$ $R N O A_{t+1}=R_{N O A}+1-R N O A, N O A_{t}$ the net operating assets $t /$ sales $t, \triangle N O A_{t}=\left(N O A_{t}-N O A_{t-1}\right) / N O A_{t-1}, D A A C_{t}$ is discretionary accruals measured by Kothari et al., (2005) model, $E M-U P_{t}=$ signal of upward EM, and $E M-D N_{t}=$ signal of downward EM.

\section{FINDINGS}

\subsection{Descriptive Statistics}

Table 2 summarizes the estimates of the parameters of the discretionary accruals model used to measure EM i.e. Kothari et al., (2005) model, the explanatory power for the model in each year as well as the descriptive statistics for these parameters. The explanatory power $\left(R^{2}\right)$ for the model in all years are quite high as compared to other studies, the average $R^{2}$ for the regression model is 0.244 which to a large degree equals the average $R^{2}$ in other related studies $\left(R^{2}=0.232\right.$ in Jones (1991), and equals 0.196 in Hoglund (2012) studies).

According to the literature, it is assumed that the sign of the coefficient of (PPE) in the model is to be negative, as th is variable represents the depreciation expense which is an income-decreasing accrual (Jones (1991). The coefficient's sign of ( $\triangle R E V)$ isn't agreed upon (PPE). For example, Jones (1991) argued that this coefficient can be positive becau se the change in revenues can cause increases in accounts receivables (income-increasing accrual), or can be negative as it may cause increases in accounts payables i.e. income-decreasing accrual. Höglund (2010) on the other hand, argued that the coefficient for change in revenues is expected to be positive, as, for most companies, accounts receivables increase more than accounts payables when revenues increase. Consistent with what is mentioned, the sign of PPE's coefficient is almost negative in all years, and the average estimated coefficient of this variable is significantly negative. The sign of $\triangle R E V$ 's coefficient is almost negative in all years, but the average estimated coefficient of this variable is positive, it is can be explained as Palestinian firms, on average, have accounts payable credit gre ate $r$ than accounts receivables in years in which the coefficient sign is negative.

Table 3 summarizes the descriptive statistics of the main variables in the study. The table includes a new me $n t i o n$ ed variable which is an indicator variable (DAAC-UP) $=1$ when DAAC is positive and zero otherwise. This variable is use d to determine the average firms which have exercised upward EM as compared to EM-UP diagnostic. According to the descriptive statistics, PM/ATO diagnostic identifies $22.3 \%$ of the sample observations as having upward EM, and $15.2 \%$ of the sample observations as having downward EM. Therefore, the diagnostic suggests that $37.5 \%$ of firms have managed earnings either up or down. In contrast, the discretionary accrual model (Kothari et al. (2005) model) identifies all firms as having managed earnings either up or down (51.7\% of firms as having upward EM (DAAC-UP = .5172 ), and $48.3 \%$ of firms as having downward EM).

Table 4 reports the percentage of observations with EM_UP, EM_DN, and DAAC_UP by ye ar. The frequency of EM_DN observations is greater than that of EM_UP in 7 of the 12 years. The years in which EM_DN is less frequent are 2015 and 2017 only. DAAC-UP, on the other hand, is greater than $50 \%$ in 7 years.

Table 2: Descriptive Statistics of Parameters' Estimates

$\frac{T A A C_{t, i}}{T A_{t-1, i}}=\propto_{0}\left(\frac{1}{T A_{t-1, i}}\right)+\propto_{1}\left(\frac{\Delta R E V_{t, i}}{T A_{t-1, i}}\right)+\propto_{2}\left(\frac{P P E_{t, i}}{T A_{t-1, i}}\right)+\alpha_{3}\left(R O A_{t}\right)$

\begin{tabular}{llllll}
\hline Variable & $\mathbf{1 / T A}$ & $\mathbf{\Delta R E V}$ & $\mathbf{P P E}$ & $\mathbf{R O A}$ & \\
Year & $\boldsymbol{\alpha}_{\mathbf{0}}$ & $\boldsymbol{\alpha}_{\mathbf{1}}$ & $\boldsymbol{\alpha}_{\mathbf{2}}$ & $\boldsymbol{\alpha}_{\mathbf{3}}$ & $\mathbf{R}^{\mathbf{2}}$ \\
\hline 2006 & 39930.12 & 1.0267 & -0.1138 & -0.3352 & $27.48 \%$ \\
2007 & -71926.2 & -0.0557 & -0.0539 & -0.3032 & $16.23 \%$ \\
2008 & -231448 & -0.0458 & -0.0883 & -0.2605 & $27.56 \%$ \\
2009 & -48857.9 & -0.1067 & -0.0249 & -0.1335 & $5.38 \%$ \\
2010 & 42483.32 & -0.0987 & 0.1008 & -0.1158 & $10.26 \%$ \\
2011 & 107465 & -0.1486 & -0.0542 & -0.2116 & $12.72 \%$
\end{tabular}




$\begin{array}{llllll}2012 & 134817.4 & -0.1469 & -0.0296 & 0.1831 & 13.66 \% \\ 2013 & -67254.3 & -0.0389 & -0.0524 & 0.6189 & 23.16 \% \\ 2014 & 74403.47 & -0.0118 & 0.05167 & 0.0163 & 7.13 \% \\ 2015 & 2083394 & -0.05995 & -0.6512 & 0.2591 & 49.55 \% \\ 2016 & -176796 & 0.0355 & -0.1286 & -0.0086 & 76.13 \% \\ 2017 & -4464.18 & 0.0498 & -0.0948 & 0.4067 & 23.50 \% \\ \text { Mean } & 156812.2 & 0.0332 & -0.0949 & 0.00964 & 24.40 \% \\ & & & & & \\ \text { Median } & 17732.97 & -0.0507 & -0.0541 & -0.06222 & 19.7 \% \\ \text { St. dev. } & 616518 & 0.3191 & 0.1871 & 0.30099 & 20.25 \% \\ \text { Positive } & 6 & 3 & 2 & 5 & - \\ \text { Negative } & 6 & 9 & 10 & 7 & -\end{array}$

Notes: TA, lagged total assets; $\triangle \mathrm{REV}$, changes in revenues; PPE, Property, plant, and equipment in period t; ROA, return on assets; $\alpha 0 \ldots \alpha$, estimated parameters from the estimation period

Table 3: Decriptive Statistics of Main Variables

\begin{tabular}{|c|c|c|c|c|c|}
\hline Variable & Mean & Median & Maximum & Minimum & Std. Dev. \\
\hline TAAC $_{t}$ & -0.0055 & -0.0200 & 2.6332 & -0.5968 & 0.1876 \\
\hline NDAAC $_{t}$ & 0.0284 & -0.0179 & 1.9638 & -0.6200 & 0.2375 \\
\hline $\mathrm{DAAC}_{\mathrm{t}}$ & -0.0338 & 0.0036 & 0.6735 & -0.9952 & 0.2206 \\
\hline DAAC-UP $_{\mathrm{t}}$ & 0.5172 & 1.0000 & 1.0000 & 0.0000 & 0.5005 \\
\hline$\triangle \mathrm{PM} \mathrm{M}_{\mathrm{t}}$ & 0.0842 & -0.0015 & 14.5215 & -14.4306 & 1.5430 \\
\hline$\Delta \mathrm{ATO}_{\mathrm{t}}$ & 0.0109 & 0.0140 & 14.0303 & -12.9364 & 1.3574 \\
\hline$E M-U P_{t}$ & 0.1516 & 0.0000 & 1.0000 & 0.0000 & 0.3592 \\
\hline$E M-D N_{t}$ & 0.2226 & 0.0000 & 1.0000 & 0.0000 & 0.4167 \\
\hline $\mathrm{RNOA}_{\mathrm{t}}$ & 0.0506 & 0.0315 & 0.9299 & -2.0490 & 0.2099 \\
\hline$\triangle \mathrm{RNOA}_{\mathrm{t}}$ & 0.0017 & -0.0013 & 2.6297 & -2.3604 & 0.2393 \\
\hline$\Delta \mathrm{RNOA}_{\mathrm{t}+1}$ & -0.0029 & -0.0014 & 2.6297 & -2.3604 & 0.2391 \\
\hline$N^{\prime} A_{t}$ & 8.9260 & 1.5499 & 749.0532 & -7.9704 & 46.4019 \\
\hline$\Delta \mathrm{NOA}_{\mathrm{t}}$ & 0.0805 & -0.0343 & 9.5464 & -19.8999 & 1.5816 \\
\hline
\end{tabular}

Notes: TAAC, Total accruals in period t; NDAAC, nondiscretionary (normal) accruals; DAAC $\mathrm{t}_{\mathrm{t}}$ discretionary accruals measured by Kothari model; DAAC-UP, discretionary accruals upward; $\triangle P M_{T}$, change in profit Margin Ratio; $\triangle A T O_{t}$, change in asset turnover ratio; EM-UP, a signal of upward EM; EM-DNs, a signal of downward EM; RNOA $A_{t}$, return on net operating assets; $\triangle R N O A_{t+1}$, change in RNOA $; \quad \triangle R N O A_{t+1}, \triangle R N O A_{t+1}-R N O A_{t} ; N_{t} A_{t}$, net operating assets/sales; $\Delta$ not $_{t}$, change in $N A_{t}$.

Table 4: Descriptive Statistics of EM-UP, EM-DN, and DAAC-UP by year

\begin{tabular}{lllll}
\hline & EM-UP & EM-DN & DAAC-UP & n \\
\hline 2006 & $11 \%$ & $26 \%$ & $79 \%$ & 19 \\
2007 & $9 \%$ & $23 \%$ & $68 \%$ & 22 \\
2008 & $12 \%$ & $24 \%$ & $72 \%$ & 25 \\
2009 & $15 \%$ & $15 \%$ & $54 \%$ & 26 \\
2010 & $7 \%$ & $22 \%$ & $26 \%$ & 27
\end{tabular}




$\begin{array}{lllll}2011 & 4 \% & 29 \% & 61 \% & 28 \\ 2012 & 4 \% & 7 \% & 36 \% & 28 \\ 2013 & 21 \% & 21 \% & 57 \% & 28 \\ 2014 & 7 \% & 26 \% & 7 \% & 27 \\ 2015 & 22 \% & 15 \% & 7 \% & 27 \\ 2016 & 12 \% & 96 \% & 26 \\ 2017 & 15 \% & 12 \% & 73 \% & 26 \\ \text { Notes: For the definition of variables, refer to Table 3. }\end{array}$

\subsection{Pearson Correlation}

Table 5 presents the Pearson correlation coefficient matrix for all variables that are used in the study. As presented in the table, there are significant relationships between EM-UP, EM-DN, and the most of other variables which means that PM/ATO diagnostic captures a substantial amount of the information relative to these variables (Jansen et al., 2012).

Regarding the relationship between PM/ATO diagnostic and the discretionary accruals (DAAC) obtained from the modified version of Jones model (1991), i.e. Kothari et al., (2005) model, the positive correlation between EM-UP and discretionary accruals (DAAC) of (.05) and the negative correlation between EM-DN and DAAC of (-.0402) are consistent with results in Jansen et al., (2012) study. These correlations, however, are statistically significant at on ly a $75 \%$ confidence level.

By using future profitability reversals as an indicator of earnings management, a negative correlation between $\triangle R N O A_{t+1}$ (a proxy for future profitability) and EM-UP, and a positive correlation between $\triangle R N O A_{t+1}$ and EM-DN are expected. Consistent with these assumptions, there's a significant negative correlation of (-.1662) between $\triangle R N O A_{t+1}$ and EM-UP, and a significant positive correlation of (.0999) between $\triangle R N O A_{t+1}$ and EM-DN. Besides, there's a significant negative correlation of (-.1743) between $\triangle$ RNOA $_{t+1}$ and DAAC. Therefore, taking future profitability reversal as a proxy of EM, it appears that EM-UP and EM-DN identify upward and downward EM respectively.

Table 5: Pearson Correlation

\begin{tabular}{|c|c|c|c|c|c|c|c|c|}
\hline & $\Delta \mathrm{PM}_{\mathrm{t}}$ & $\Delta \mathrm{ATO}_{\mathrm{t}}$ & DAAC $_{t}$ & $\triangle \mathrm{RNOA}_{\mathrm{t}}$ & $\Delta \mathrm{RNOA}_{\mathrm{t}+1}$ & EM-UP $_{t}$ & $E M-D N_{t}$ & $\mathrm{RNOA}_{t}$ \\
\hline$\triangle \mathrm{PM} \mathrm{M}_{\mathrm{T}}$ & 1 & & & & & & & \\
\hline$\Delta \mathrm{ATO}_{\mathrm{t}}$ & -0.0045 & 1 & & & & & & \\
\hline DAAC $_{t}$ & -0.0684 & $0.1005^{*}$ & 1 & & & & & \\
\hline$\triangle \mathrm{RNOA}_{\mathrm{t}}$ & $-0.5812 * *$ & $0.4055^{* *}$ & $0.1720 * *$ & 1 & & & & \\
\hline$\triangle \mathrm{RNOA}_{\mathrm{t}+1}$ & $0.3285 * *$ & $-0.2208 * *$ & $-0.1743 * *$ & $-0.4562 * *$ & 1 & & & \\
\hline$E M-U P_{t}$ & 0.0952 & $-0.1033^{*}$ & 0.0500 & 0.0294 & $-0.1662 * *$ & 1 & & \\
\hline EM-DN $\mathrm{t}_{\mathrm{t}}$ & $-0.1288^{*}$ & $0.0969 *$ & -0.0402 & -0.0432 & $0.0999 *$ & $-0.2271^{* *}$ & 1 & \\
\hline $\mathrm{RNOA}_{\mathrm{t}}$ & $-0.3846 * *$ & $0.2490 * *$ & $0.1411^{* *}$ & $0.6024 * *$ & $-0.5934^{* *}$ & -0.0935 & -0.0021 & 1 \\
\hline
\end{tabular}

\subsection{Contingency Tables}

Using DAAC as a proxy for earnings management, the Pearson correlation coefficient was found for EM-UP/ EM-DN. However, the coefficient is very sensitive to extreme data values and a low Pearson coefficient does not mean that no relationship exists between the variables. Therefore, contingency tables are used to measure the association between two dichotomous variables. First, DAAC-UP (DAAC-DN) was examined as an indicator of upward (downward) earnings manage ment which equals one when DAAC is positive (negative) and zero otherwise. Then the association be twe e $n$ EM-UP/ EM-DN and DAAC-UP/ DAAC-DN respectively was tested using contingency tables and chi-square statistics. 
Table 6 panel A presents how much PM/ATO diagnostic corresponds with the discretionary accrual model in identifying upward/ downward earnings management. Panel $A$ in the table reports the percentage of observations when EM-UP equals zero or one as compared to the percentage when DAAC-UP equals zero or one. When DAAC-UP is equal to zero EM-UP is equal to zero in $92.6 \%$ of observations, and equal to one in $7.4 \%$ of observations. On the other hand, when DAAC-UP is equal to one, EM-UP is equal to zero in $84.4 \%$ of observations and equal to one in $15.6 \%$ of observations. Therefore, upward diagnostic (EM-UP) identifies upward EM (when DAAC is positive, DAAC-UP = 1) twice than when DAAC is negative i.e. DAAC-UP $=0$ (15.6\% versus $7.4 \%)$. Accordingly, a test of proportions using the Phi coefficient (a Pearson coefficient used when two variables are dichotomous) and chi-square statistics show that there is a significant positive relationship between DAAC-UP and EM-UP.

Similarly, Panel B in table 6 presents the percentage of observations when EM-DN is equal to zero or one as compared to the percentage when DAAC-DN is equal to zero or one. When DAAC-DN is equal to zero EM-DN is equal to ze ro in $80.6 \%$ of observations, and equal to one in $19.4 \%$ of observations. On the other hand, when DAAC-DN is equal to one, EM-DN is equal to zero in $79.9 \%$ of observations and equal to one in $20.1 \%$ of observations.

The test of proportions shows that EM-DN cannot indicate downward earnings management as measured by DAACDN. EM-DN indicates downward earnings management when DAAC is negative i.e. DAAC-DN equals one, almost the same as often when DAAC is positive i.e. DAAC-DN equals zero $(20.1 \% / 19.4 \%=1)$. Therefore, and according to the Phi coefficient and chi-square statistic, there is a positive but not statistically significant relationship between EM-DN and DAAC-DN.

Table 6: Contingency Tables the Association between DAAC-UP and EM-UP

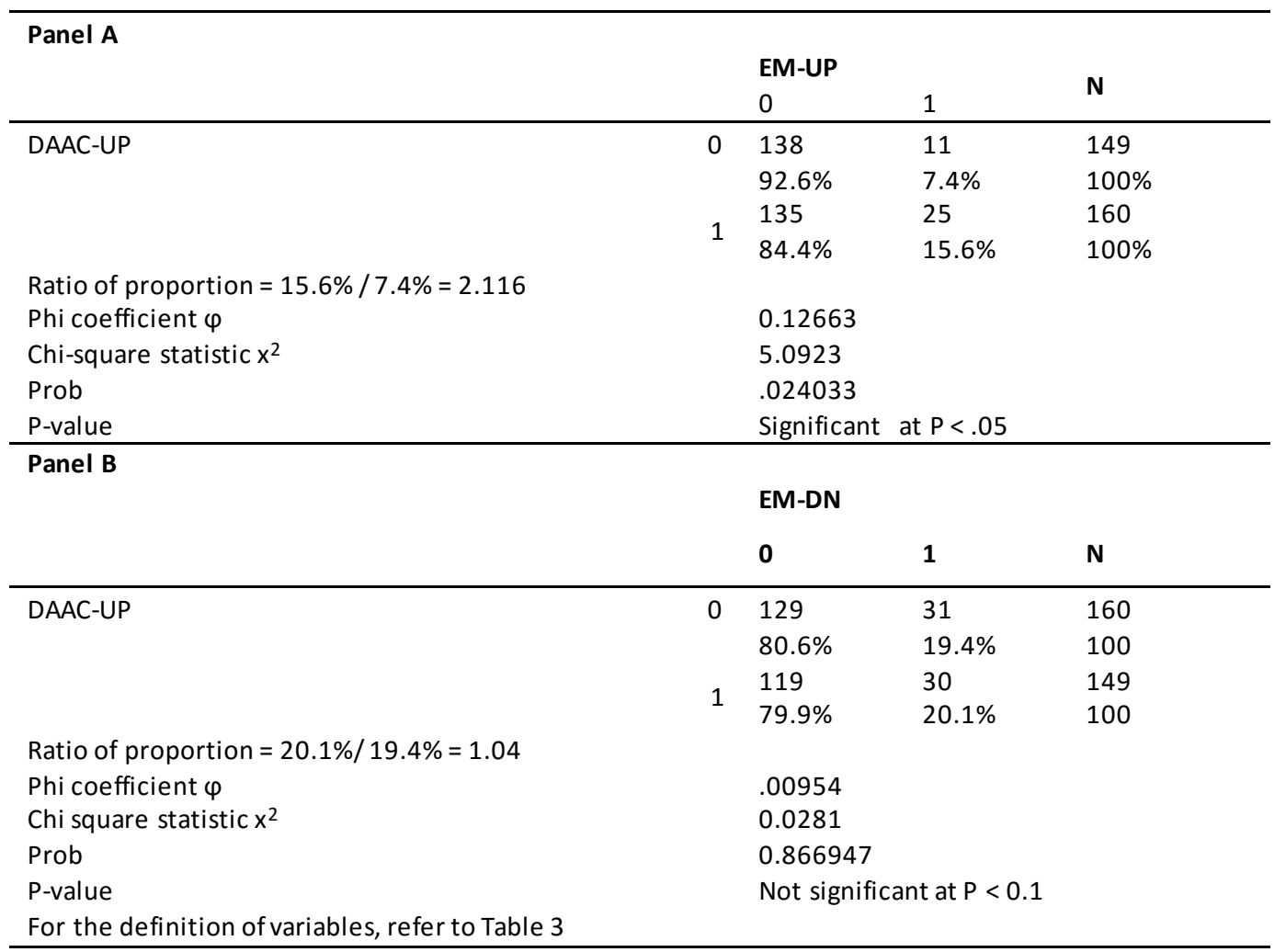

\subsection{Multivariate Analysis}

Using the reversal of future profitability as a proxy of earnings management to investigate the ability of this diagnostic in identifying earnings management as compared to the discretionary accrual model. Jansen et al., (2012) used a model for predicting one-year ahead profitability $\triangle R N O A_{t+1}$ and insert control variables which have been identified by previous studies: RNOA, $\triangle R N O A, N O A$, and $\triangle N O A$ (e.g. (Fairfield and Yohn, 2001). According to what was mentioned, a negative coefficient is expected on EM-UP and a positive coefficient is expected on EM-DN.

The coefficients of the control variables in the regression models were used to predict $\triangle R N O A_{t+1}, t$-statistics, and adjusted R square for each model reported in the table VII. The first model includes the control variables as used in previous studies (Fairfield \& Yohn, 2001), the coefficient for all these variables are significant, the adjusted $R^{2}$ for the model is high (42.56\%) as compared to the results in Jansen et al. (2012) study ( $R^{2}$ for the first model equals $4.08 \%$ ). 
In the second model, the diagnostic indicators (EM-UP and EM-DN) have been added to investigate the ability of the diagnostic in explaining future profitability. As presented in the table, there is a significant positive correlation for EMUP, and a significant positive correlation for EM-DN, which is consistent with Pearson correlation results presented in the first test. However, EM-UP's correlation is only marginally significant at $(P<.25)$, and EM-DN's coefficient is still statistically significant at $(P<.05)$. The explanatory power of the model $(R 2)$ is $43.18 \%$ which greater than $R 2$ for the first original model which equals $42.56 \%$ indicating that the PM/ATO diagnostic is informative in explaining future profitability. Therefore, using reversals in future profitability as a proxy for earnings management, it is concluded that PM/ATO diagnostic is successful in identifying earnings management.

The discretionary accruals (DAAC) have been included in the third model. consistent with the reversal in discretionary accruals documented in prior research (Dechow et al., 2003), there's a significant positive correlation for DAAC which is consistent with the Pearson correlation results presented above. However, the correlation here is significant at a $90 \%$ confidence level as compared to $95 \%$ in the Pearson correlation results. The adjusted R2 for the model is $42.69 \%$, which is lower than the adjusted $\mathrm{R}^{2}$ for the second model included EM-UP and EM-DN, indicating that the PM/ATO diagnostic has incremental information in identifying EM as proxied by future profitability reversals.

Table 7 reports estimation results from the following models:

$$
\begin{aligned}
& \Delta \mathrm{RNOA}_{\mathrm{t}+1}=\beta_{0}+\beta_{1} \mathrm{RNOA}_{\mathrm{t}}+\beta_{2} \mathrm{NOA}_{\mathrm{t}}+\beta_{3} \Delta \mathrm{RNOA}_{\mathrm{t}}+\beta_{4} \Delta \mathrm{NOA}_{\mathrm{t}}+\varepsilon_{\mathrm{t}} \\
& \Delta \mathrm{RNOA}_{\mathrm{t}+1}=\beta_{0}+\beta_{1} \mathrm{RNOA}_{\mathrm{t}}+\beta_{2} \mathrm{NOA}_{t}+\beta_{3} \Delta \mathrm{RNOA} \mathrm{A}_{\mathrm{t}}+\beta_{4} \Delta \mathrm{NOA}_{\mathrm{t}}+\beta_{5} \mathrm{EM}-\mathrm{UP}_{t_{\mathrm{t}}}+\beta_{6} \mathrm{EM}_{\mathrm{DN}_{\mathrm{t}}}+\varepsilon_{\mathrm{t}} \\
& \triangle R N O A_{t+1}=\beta_{0}+\beta_{1} \mathrm{RNOA}_{\mathrm{t}}+\beta_{2} \mathrm{NOA}_{\mathrm{t}}+\beta_{3} \Delta \mathrm{RNOA}_{\mathrm{t}}+\beta_{4} \Delta \mathrm{NOA}_{\mathrm{t}}+\beta_{5} \mathrm{DAAC}_{\mathrm{t}}+\varepsilon_{\mathrm{t}} \\
& \Delta R N O A_{t+1}=\beta_{0}+\beta_{1} \text { RNOA }_{t}+\beta_{2} \text { NOA }_{t}+\beta_{3} \Delta \mathrm{RNOA}_{\mathrm{t}}+\beta_{4} \Delta \mathrm{NOA}_{\mathrm{t}}+\beta_{5} \mathrm{DAAC}_{\mathrm{t}}+\beta_{6} \mathrm{EM}-\mathrm{UP}_{t_{\mathrm{E}}}+\beta_{7} \mathrm{EM}_{\mathrm{DN}_{\mathrm{t}}}+\varepsilon_{\mathrm{t}}
\end{aligned}
$$

\begin{tabular}{|c|c|c|c|c|c|c|c|c|c|}
\hline Model & Intercept & RNA & NOA & RNA $\Delta$ & NOA $\Delta$ & DOC & EM-UP & EM-DN & $\begin{array}{l}\text { Adjusted } \\
\mathbf{R}^{2}\end{array}$ \\
\hline \multirow[t]{2}{*}{1} & $0.0233^{* * *}$ & $\begin{array}{l}- \\
0.4692^{* * *}\end{array}$ & $0.0004 * *$ & $\begin{array}{l}- \\
0.1152^{* * *}\end{array}$ & $\begin{array}{l}- \\
0.0443^{* * *}\end{array}$ & & & & $42561 \%$ \\
\hline & $(1.99)$ & $(-6.81)$ & $(1.65)$ & $(-2.07)$ & $(-5.65)$ & & & & \\
\hline \multirow[t]{2}{*}{2} & $0.0292^{* * *}$ & $\begin{array}{l}- \\
0.4564 * * *\end{array}$ & $0.0003 * *$ & $\begin{array}{l}- \\
0.1205^{* * *}\end{array}$ & $\begin{array}{l}- \\
0.0454^{* * *}\end{array}$ & & $-0.0293 *$ & $0.0470 * * *$ & $\% 43.18$ \\
\hline & (1.99) & $(-6.63)$ & (1.62) & $(-2.18)$ & $(-5.81)$ & & $(-0.93)$ & (1.75) & \\
\hline \multirow[t]{2}{*}{3} & $0.0206^{* * *}$ & $\begin{array}{l}- \\
0.4670^{* * *}\end{array}$ & $0.0004 * *$ & $\begin{array}{l}- \\
0.1080 * * *\end{array}$ & $\begin{array}{l}- \\
0.0435^{* * *}\end{array}$ & $-0.0639 * *$ & & & $\% 42.69$ \\
\hline & (1.73) & $(-6.79)$ & (1.64) & $(-1.94)$ & $(-5.54)$ & $(-1.27)$ & & & \\
\hline \multirow[t]{2}{*}{4} & $0.0262^{* * *}$ & $\begin{array}{l}- \\
0.4541^{* * *}\end{array}$ & $0.0004 * *$ & $\begin{array}{l}- \\
0.1134 * * *\end{array}$ & $\overline{0.0447^{* * *}}$ & $-0.0634^{*}$ & $-0.0304 *$ & $0.0461^{* * *}$ & $\% 43.31$ \\
\hline & $(1.76)$ & $(-6.61)$ & (1.61) & $(-2.04)$ & $(-5.70)$ & $(-1.27)$ & $(-0.97)$ & $(1.72)$ & \\
\hline
\end{tabular}

Table 7: The Association between EM-UP, EM-DN, DAAC, and Future Profitability $\triangle R N O A t+1$

For the definition of variables, refer to Table $3 . *, * *, * *$ significant at $0.10,0.05$ and 0.01 respectively

Finally, Fairfield and Yohn (2001) demonstrate that disaggregating current return on net operating assets (RNOA) into the change in asset turnover $(\triangle \mathrm{ATO})$ and the change in profit margin $(\triangle \mathrm{PM})$ is useful for forecasting one -year-ahead profitability. Therefore, it's relevant to investigate whether the improvement in the explanatory power of the model mentioned above because of PM/ATO diagnostic i.e. the sign interaction between ( $\triangle \mathrm{ATO}$ ) and $(\triangle \mathrm{PM})$, or because $(\triangle P M)(\triangle A T O)$ themselves as they are components of this diagnostic (Jansen et al. 2012). Hence, both ( $\triangle P M),(\triangle A T O)$ will be added to the original model for predicting $\left(\triangle \mathrm{RNOA} \mathrm{A}_{\mathrm{t}+1}\right)$ as control variables, and tracing the improve $m$ e $n t$ on the explanatory power of this model as EM indicators (EM-UP, EM-DN, DAAC) are included to the model.

Table 8 presents the coefficients of the control variables, $t$ statistics, and squared $R$ for each model. The fifth model includes $(\triangle P M)$ and $(\triangle A T O)$ as control variables. Consistent with Fairfield and Yohn (2001), the explanatory power of the first model increased from $(42.561 \%)$ in the table VII to $(45.346 \%)$ in the table VIII when $(\triangle \mathrm{PM})$ and $(\Delta$ ATO) are added to the model. There's a significant negative coefficient of $\triangle A T O$ at a $95 \%$ confidence level, and a negative coefficient of $\triangle P M$ but marginally significant at a $75 \%$ confidence level.

In model (6), EM-UP and EM-DN have been added to the model, the coefficient of EM-UP is still negative and significant at only a 75\% confidence level, and the coefficient of EM-DN is still positive and significant at a $95 \%$ confidence level. The explanatory power (R2) improved from (45.346\%) in the model (5) to (45.911\%) in the model 
(6), which indicates that the PM/ATO is informative in identifying future profitability even though, $(\triangle P M)$ and $(\triangle A T O)$ are added to the original model. Also, the explanatory power of the model (7) which includes discretionary accruals (DAAC) decreased as compared to the model (6). Therefore, it can be concluded that PM/ATO diagnostic outperform s discretionary accruals in identifying EM when using future profitability reversals as a proxy of EM.

Table 8 presents the estimation results for the following models:

(5) $\quad \Delta R N O A_{t+1}=\beta_{0}+\beta_{1} \mathrm{RNOA}_{\mathrm{t}}+\beta_{2} \mathrm{NOA}_{\mathrm{t}}+\beta_{3} \Delta \mathrm{RNOA}+\beta_{4} \Delta N O A_{\mathrm{t}}+\beta_{5} \Delta \mathrm{PM}+\beta_{6} \Delta \mathrm{ATO} \varepsilon_{\mathrm{t}}$ $\Delta \mathrm{RNOA}_{\mathrm{t}+1}=\beta_{0}+\beta_{1} \mathrm{RNOA}_{\mathrm{t}}+\beta_{2} \mathrm{NOA}_{t}+\beta_{3} \Delta \mathrm{RNOA}_{\mathrm{t}}+\beta_{4} \Delta \mathrm{NOA}_{\mathrm{t}}+\beta_{5} \Delta \mathrm{PM}_{t}+\beta_{6} \Delta \mathrm{ATO}_{t}+\beta_{7} \mathrm{EM}-\mathrm{UP}_{t}+$

(6) $\quad \beta_{8} \mathrm{EM}-\mathrm{DN}_{t}+\varepsilon_{\mathrm{t}}$

(7) $\quad \Delta R N O A_{t+1}=\beta_{0}+\beta_{1} \mathrm{RNOA}_{\mathrm{t}}+\beta_{2} \mathrm{NOA}_{\mathrm{t}}+\beta_{3} \Delta \mathrm{RNOA}_{\mathrm{t}}+\beta_{4} \Delta \mathrm{NOA}_{\mathrm{t}}+\beta_{5} \Delta \mathrm{PM}_{t}+\beta_{6} \Delta \mathrm{ATO}_{t}+\beta_{7} \mathrm{DAAC}_{\mathrm{t}}+\varepsilon_{\mathrm{t}}$

$\Delta R N O A_{t+1}=\beta_{0}+\beta_{1}$ RNOA $_{t}+\beta_{2}$ NOA $_{t}+\beta_{3} \Delta \mathrm{RNOA}_{\mathrm{t}}+\beta_{4} \Delta \mathrm{NOA}_{\mathrm{t}}+\beta_{5} \Delta \mathrm{PM}_{t}+\beta_{6} \Delta \mathrm{ATO}_{t}+\beta_{7} \mathrm{DAAC}_{\mathrm{t}}+\beta_{8} \mathrm{EM}-1$

(8) $\quad \beta_{9} \mathrm{EM}-\mathrm{DN}_{\mathrm{t}}+\varepsilon_{\mathrm{t}}$ 


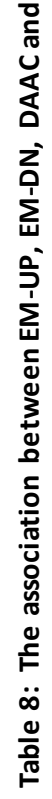

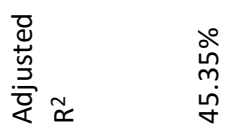

$\sum_{\text {ì }}^{z}$

$\sum_{\substack{1 \\ 1}}^{0}$

ญ̆

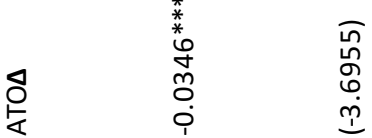

$\sum_{0} \quad \stackrel{\circ}{\circ} \quad \stackrel{\circ}{\circ}$

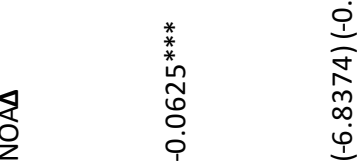

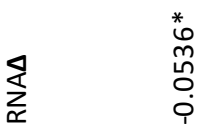

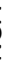

$\stackrel{*}{*}$
$\stackrel{*}{*}$
$\stackrel{*}{N}$
$\stackrel{N}{0}$
0

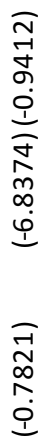

๔ $\stackrel{*}{*} \stackrel{*}{*}$
กิ

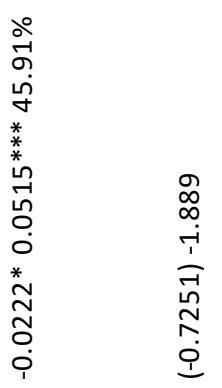

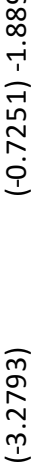

ถุต

포
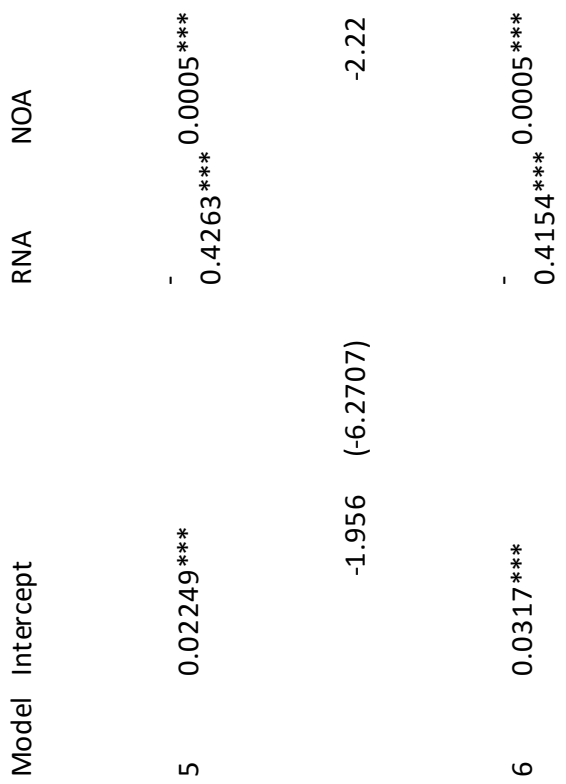

ने
ஸे

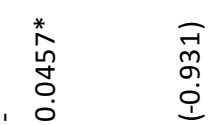

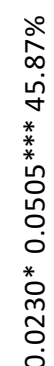

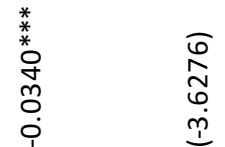

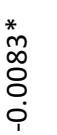

क
in
$\infty$
0
0
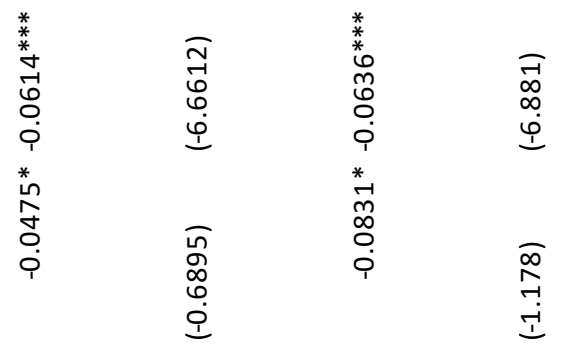

$\stackrel{*}{*}$

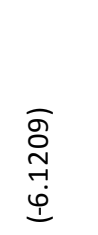

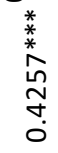

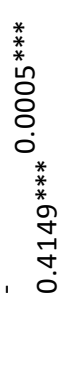

の
ศ్
-

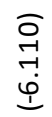

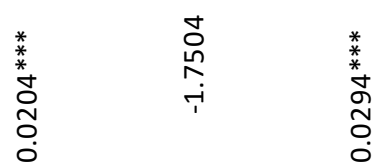

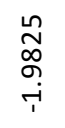

$\infty$ 


\section{SUMMARY AND CONCLUSION}

The purpose of this paper is to investigate the ability of ATO/PM diagnostic proposed by Jansen et al. (2012) as a simplistic indicator in identifying accrual-based EM. The need for testing such simple diagnostic is crucial as the existing aggregate accrual models, which are the most popular models used in the literature review, are suffering from several problems such as lack of power and specification as well as they are timing consuming and need complicated calculations to be utilize d. The investigation of the diagnostic effectiveness was performed by applying two tests. The results of these tests were consistent, to a large extent, with the propositions argued by Jansen et al. (2012) study as well as the results of the preceding studies such as Harebottle (2016); Hejazi et al. (2014) that investigated the ability of the diagnostic in identifying earnings management.

The results of the tests performed in this study were as follows: according to the first test in which the Kothari et al., (2005) model was used as a proxy of EM, the positive Pearson correlation (significant only at $75 \%$ confidence level) be twe en EMUP (signal of upward EM) and discretionary accruals (DAAC) obtained from Kothari et al. model (2005), and the statistically significant relationship between EM-UP and DAAC-UP (indicator $=1$ when DAAC is positive) at $95 \%$ confidence level obtained from using contingency tables are consistent with the results of Jansen et al. (2012) study. Supporting to these results, by using one-year ahead profitability $\left(\Delta R N O A_{t+1}\right)$ as an indicator of $E M$, the negative statistically significant correlation between EM-UP and $\left(\triangle R N O A_{t+1}\right)$ of (-.1662) also supports the argument that firms with simultaneous increase of PM and decrease of ATO managed earnings up in the current period and will have lower profitability in the subsequent period. Depending on the preceding results, the first hypothesis of the "simultaneous increase of PM and the decrease of ATO is a sign of upward earnings management" can be accepted.

Similarly, the negative Pearson correlation of (-.0402) between EM-DN (signal of downward EM) and DAAC is consistent also with Jansen et al. (2012) results. Although the correlation between EM-DN and DAAC-DN obtained from contingency tables was not strong enough as EM-UP (the Phi correlation coefficient was only .00954 for EM-DN versus 0.12663 Phi coefficient for EM-UP), the positive Pearson correlation between EM-DN and one-year ahead profitability $\left(\triangle R_{N} N A_{t+1}\right)$ of (0.0999) was statistically significant to confirm that firms with simultaneous decrease of PM and increase of ATO managed earnings down in the current period and will have higher profitability in the subsequent period. Therefore, by depending on $\left(\Delta \mathrm{RNOA}_{\mathrm{t}+1}\right)$ as an indicator for EM, the second hypothesis of "simultaneous decrease of PM and increase of ATO is a sign of downward earnings management" is accepted.

The second test was performed to investigate whether the PM/ATO diagnostic is more informative in identifying EM as compared to S. P. Kothari et al. (2005) model. By initially applying the regression model proposed by Jansen et al. (2012) to predict one-year ahead profitability, and the stepwise regression forward selection method was used to trace the improvement achieved to the adjusted squared $\mathrm{R}$ of the basic regression model as each indicator of the EM (PM/ATO diagnostic and DAAC) was added to the model.

Based on the empirical results, the sign of the coefficients of EM-UP, EM-DN, and DAAC as control variables in the model used to predict $\left(\triangle R N O A_{t+1}\right)$ are consistent with the Pearson correlation with $\left(\triangle R N O A_{t+1}\right)$ results in the first test i.e. ne gative coefficient of EM-UP and DAAC, and positive coefficient of EM-DN. By tracing the adjusted squared $\mathrm{R}$ of the regression model used to predict $\left(\triangle R N O A_{t+1}\right)$, it's can be concluded that PM/ATO diagnostic provides incremental information in identifying EM as compared to S. P. Kothari et al. (2005) model ( $R^{2}$ of the second model included the diagnostic equals 0.4318 which is higher than $R^{2}$ which equals 0.4269 of the third model included DAAC). Also, after adding ( $\left.\triangle A T O\right)$ and $(\triangle P M)$ as control variables to the original model, the inclusion of EM-UP/EM-DN indicators still causes improvement to the explanatory power of the model. These results are consistent with the results of Harebottle (2016); Hejazi et al. (2014); Jansen et al. (2012) studies which found that PM/ATO diagnostic is more informative in identifying EM over aggregate accrual EM models.

Depending on what is mentioned above, and by using one-year ahead profitability $(\triangle \mathrm{RNOA} t+1)$ as a proxy of EM, the third hypothesis of " The PM/ATO diagnostic provides incremental information content over discretionary accruals in identifying earnings management."

\section{Further research}

As accrual-based earnings management was the focus of this paper, further research could include the investigation of re al earnings management for the Palestinian public firms or firms from other emerging economies to provide evidence of 
whether real earnings management occurs in such economies. Another extension would be the investigation of PM/ATO diagnostic in other Arab countries to provide more evidence on the effectiveness of this diagnostic across emerging economies. In this paper, S. P. Kothari et al. (2005) accrual model was used as a proxy of earnings management to be compared with the PM/ATO diagnostic. However, numerous models have been developed to detect earnings management. Therefore, further research would use another accrual-based model, specifically, as empirical studies provide evidence that accrual models vary in their predictive power and specification (Dechow et al., 1995; Kothari et al., 2005).

\section{REFERENCES}

Abdelkarim, N., \& Zurich, K., (2020). Corporate Governance and Earnings Management: Evidence from Listed Firms at Palestine Exchange. Asian Economic and Financial Review, 10 (2), 200-217.

Alzoubi, E.S.S., (2018), "Audit quality, debt financing, and earnings management: Evidence from Jordan", Journal of International Accounting, Auditing and Taxation, 30 (3), 69-84

Alareeni, B., \& Aljuaidi, O. (2014), "The modified jones and Yoon models in detecting earnings management in Palestine Exchange (PEX)", International Journal of Innovation and Applied Studies, 9 (4), 1472.

Alghamdi, S., \& Ali, L. (2012) "The investigation into earnings management practices and the role of corporate governance and external audit in emerging markets: Empirical evidence from Saudi listed companies. Durham University.

Badertscher, B. A. (2011), "Overvaluation and the choice of alternative earnings management mechanisms", The Accounting Review, 86 (5), 1491-1518.

Beaver, W. H., \& Demski, J. S. (1979), "The nature of income measurement" Accounting Review, 54 (1), 38-46.

Beneish, M. D. (2001), "Earnings management: A perspective". Managerial Finance, 27 (12), 3-17.

Bhuiyan, M. B., Roudaki, J., \& Clark, M. B. (2013), "Corporate governance compliance and discretionary accruals: New Zealand evidence", Business and Finance Journal, 7 (2), 101-124.

Bao, S.R. \& Lewellyn, K.B., 2017, "Ownership structure and earnings management in emerging markets - An institutionalized agency perspective", International Business Review, 26 (5) , 828-838.

Brooks, L. D., \& Buckmaster, D. A. (1976), "Further evidence of the time series properties of accounting income", The Journal of Finance, 31 (5), 1359-1373.

Chamberlain, T. W., Butt, U. R., \& Sarkar, S. (2014), "Accruals and real earnings management around debt covenant violations", International Advances in Economic Research, 20 (1), 119-120.

Cohen, D. A., \& Zarowin, P. (2008), "Economic consequences of real and accrual-based earnings management activities", Leonard Ster School of Business\& New York University, Working Paper.

Cohen, D. A., \& Zarowin, P. (2010), "Accrual-based and real earnings management activities around seasoned equity offerings", Journal of accounting and economics, 50 (1), 2-19.

DeAngelo, L. E. (1986), "Accounting numbers as market valuation substitutes: A study of management buyouts of public stockholders", Accounting Review, 400-420, 61 (3), 400-420

Dechow, P. M. (1994), "Accounting earnings and cash flows as measures of firm performance: The role of accounting accruals", Journal of accounting and economics, $8(1), 3-42$.

Dechow, P. M., \& Dichev, I. D. (2002), "The quality of accruals and earnings: The role of accrual estimation errors", The Accounting Review, $77(1), 35-59$.

Dechow, P. M., Hutton, A. P., Kim, J. H., \& Sloan, R. G. (2012), "Detecting earnings management: A new approach", Journal of accounting research, 50 (2), 275-334.

Dechow, P. M., Richardson, S. A., \& Tuna, I. (2003), "Why are earnings kinky? An examination of the earnings management expla nation", Review of Accounting Studies, 8 (2-3), 355-384.

Dechow, P. M., \& Skinner, D. J. (2000), "Earnings management: Reconciling the views of accounting academics, practitioners, and regulators", Accounting Horizons, 14 (2), 235-250.

Dechow, P. M., Sloan, R. G., \& Sweeney, A. P. (1995), "Detecting earnings management", Accounting Review, 70 (2), $193-225$.

Fairfield, P. M., \& Yohn, T. L. (2001), "Using asset turnover and profit margin to forecast changes in profitability", Review of Accounting Studies, 6 (4), 371-385. 
Freeman, R. N., \& Tse, S. Y. (1992), "A nonlinear model of security price responses to unexpected earnings", Journal of accounting research, $30(2), 185-209$.

Healy, P. M. (1985), "The effect of bonus schemes on accounting decisions", Journal of accounting and economics, 7 (1-3), 85-107.

Hejazi, R., Adampira, S., Ziarani, M. B., \& Nobakht, A. V. (2014), "A Diagnostic for Earnings Management by Using Changes in Asset Turnover and Profit Margin", International Review of Management and Business Research, 11 (11), 230-241.

Hessayri, M., \& Saihi, M. (2015), "Monitoring earnings management in emerging markets: IFRS adoption and ownership structure", Journal of Economic and Administrative Sciences, 31 (2), 86-108.

Höglund, H. (2010), "Detecting Earnings Management Using Neural Networks", http://urn.fi/URN:ISBN:978-952-232-109-1

Holthausen, R. W., \& Leftwich, R. W. (1983), "The economic consequences of accounting choice implications of costly contracting and monitoring", Journal of accounting and economics, (5),77-117.

Jaggi, B., \& Sun, L. (2006), "Financial distress and earnings management: effectiveness of independent audit committees", Whitcomb Center for Research in Financial Services (WCRFS), 06-31.

Jansen, I. P., Ramnath, S., \& Yohn, T. L. (2012), "A diagnostic for earnings management using changes in asset turnover and profit margin" Contemporary Accounting Research, 29 (1), 221-251.

Jones, J. J. (1991)," Earnings management during import relief investigations", Journal of accounting research, 29 (2), 193-228.

Kasznik, R. (1999), "On the association between voluntary disclosure and earnings management", Journal of accounting research, $371,57-$ 81.

Kothari, S. P., Leone, A. J., \& Wasley, C. E. (2005), "Performance matched discretionary accrual measur es", Journal of accounting and economics, 39 (1), 163-197.

McNichols, M., \& Wilson, G. P. (1988), "Evidence of earnings management from the provision for bad debts", Journal of accounting research, Vol. 26, pp. 1-31.

McNichols, M. F. (2001), "Research design issues in earnings management studies", Journal of accounting and public policy, 19 (4-5), 313345 .

Nelson, M. W., Elliott, J. A., \& Tarpley, R. L. (2000), "Where do companies attempt earnings management, a nd when do auditors prevent it?",N AFA 2001 New Orleans Meetings, Available at SSRN: https://ssrn.com/abstract=248129 or http://dx.doi.org/10.2139/ssrn.248129

Niu, F. F. (2006), "Corporate governance and the quality of accounting earnings: a Canadian perspective", International Journal of Managerial Finance, 2 (4), 302-327.

Penman, S. H. (2007), "Financial reporting quality: is fair value a plus or a minus?", Accounting and Business Research, 37. (sup1),33-44.

Petroni, K. R. (1992), "Optimistic reporting in the property-casualty insurance industry", Journal of accounting and economics, 15 (4), 485508.

Rani, P., Hussain, F. F., \& Chand, P. V. (2013), "Managerial incentives for earnings management among listed firms: evidence from Fiji", Global Conference on Business and finance proceedings, 7 (1),184-187.

Watts, R. L., \& Zimmerman, J. L. (1978), "Towards a positive theory of the determination of accounting standards", Accounting Review, 53 (1), 112-134.

Yoon, S. S., Miller, G., \& Jiraporn, P. (2006), "Earnings management vehicles for Korean firms", Journal of International Financial Management \& Accounting, 17 (2),85-109. 